\title{
Effect of the desorption process on photoluminescence excitation spectra of porous silicon
}

\author{
T. V. Torchinskaya, N. E. Korsunskaya, L. Yu. Khomenkova, B. R. Dzhumaev \\ Institute of Semiconductor Physics, NAS Ukraine, 45 prospekt Nauki, Kyiv, 252028, Ukraine
}

A. Many, Y. Goldstein, E. Savir

Racah Institute of Physics, The Hebrew University, Jerusalem, ISRAEL

\begin{abstract}
Photoluminescence (PL), photoluminescence excitation (PLE) and FTIR methods were used to study the PL excitation mechanism in porous silicon (PS). Two types of PLE spectra were observed, consisting of two (visible and ultraviolet) and one (only ultraviolet) bands. The intensities of each PLE band depend differently on the anodization conditions during aging and thermal treatment. Two excitation channels were shown to exist in PS. The visible PLE band at $300 \mathrm{~K}$ was attributed to light absorption of some species on the surface of Si wires.
\end{abstract}

Keywords: Photoluminescence; excitation; porous silicon; desorbtion.

Paper received 16.07.98; revised manuscript received 02.09.98; accepted for publication 27.10.98.

\section{Introduction}

In spite of a large body of research made on the photoluminescence (PL) of porous silicon (PS), the origin of visible light emission (silicon wires or substances on their surface) and the mechanism of its excitation are still unknown.

In this paper, PL and PL excitation (PLE) measurements and FTIR methods were employed to study the mechanism of PL excitation in porous silicon. To elucidate the role of surface substances in the photoluminescence of porous silicon, three approaches were used, involving studies of: (i) the dependences of the PL and PLE spectra on the anodization conditions; (ii) the effect of thermal and ultrasound treatment on the PL, PLE and FTIR spectra, and (iii) aging phenomena in air and vacuum by the techniques of PL and, especially, PLE.

It should be noted that up to now, dependences of the PLE spectra on the conditions of preparation and aging have not been studied systematically.

\section{Experimental results and discussion}

Porous silicon samples were prepared from p-type B-doped, (100) oriented silicon wafers with the resistivity of $4.5 \Omega \cdot \mathrm{cm}$ by anodization in the solution of $\mathrm{HF}: \mathrm{H}_{2} \mathrm{O}: \mathrm{C}_{2} \mathrm{H}_{5} \mathrm{OH}=1: 1: 2$. The current density $\left(I_{a}\right)$ and time $\left(t_{a}\right)$ of anodization were $25,50,100,200 \mathrm{~mA} / \mathrm{cm}^{2}$ and $2,8,15 \mathrm{~min}$ respectively. Photoluminescence was excited with the light of a Xe lamp passed through the MDR-23 monochromator. XPS measurements were performed with the LAS 2000 (RIBER) spectrometer in the energy range of 0 to $1000 \mathrm{eV}$.
The photoluminescence (PL) and photoluminescence excitation (PLE) spectra are shown in fig. 1 and fig. 2 respectively. The PLE spectrum consists of two overlapping bands represented by a broad maximum in the visible spectral range (380-450 $\mathrm{nm}$ ) (V band) and a steep rise (or maximum) in the ultraviolet range (UV band).

It is essential that positions of the PL peaks depend on the wavelength of the excitation light. Namely, the peak of the photoluminescence excited by the light from the UV band $\left(\mathrm{W}_{\mathrm{UV}}\right)$ is located at shorter wavelengths than that of PL excited by the light from the $\mathrm{V}$ band $\left(\mathrm{W}_{\mathrm{V}}\right)$ (fig. 1(c)).

\subsection{Dependence of PL and PLE spectra on anodization conditions}

An increase in the anodization current density results in a shift of PL towards shorter wavelengths and in a decrease of the PL intensity and its full width at half maximum (FWHM) independently of the excitation light wavelength (fig. 1(a)). The latter effect takes place mainly in the case of the UV excitation. At the same time, the intensity of the $\mathrm{V}$ band in the PLE spectrum decreases, and at the density of anodization current $I_{a}=200 \mathrm{~mA} / \mathrm{cm}^{2}$ this band eventually disappears (fig. 2(a)). Comparison of the curves shown in fig. 2 makes it possible to estimate the overlapping range of the $\mathrm{V}$ and UV excitation bands. This range covers the range from 350 to $450 \mathrm{~nm}$ at least.

Longer anodization times lead to a shift of the PL peak toward longer wavelengths and a rise of the PL intensity and its FWHM (fig. 1(b)). The intensity of the V band in the PLE spectrum also increases (fig. 2(b)). These data indicate 


\section{T. V. Torchinskaya et al.: Effect of desorption on photoluminescence excitation...}

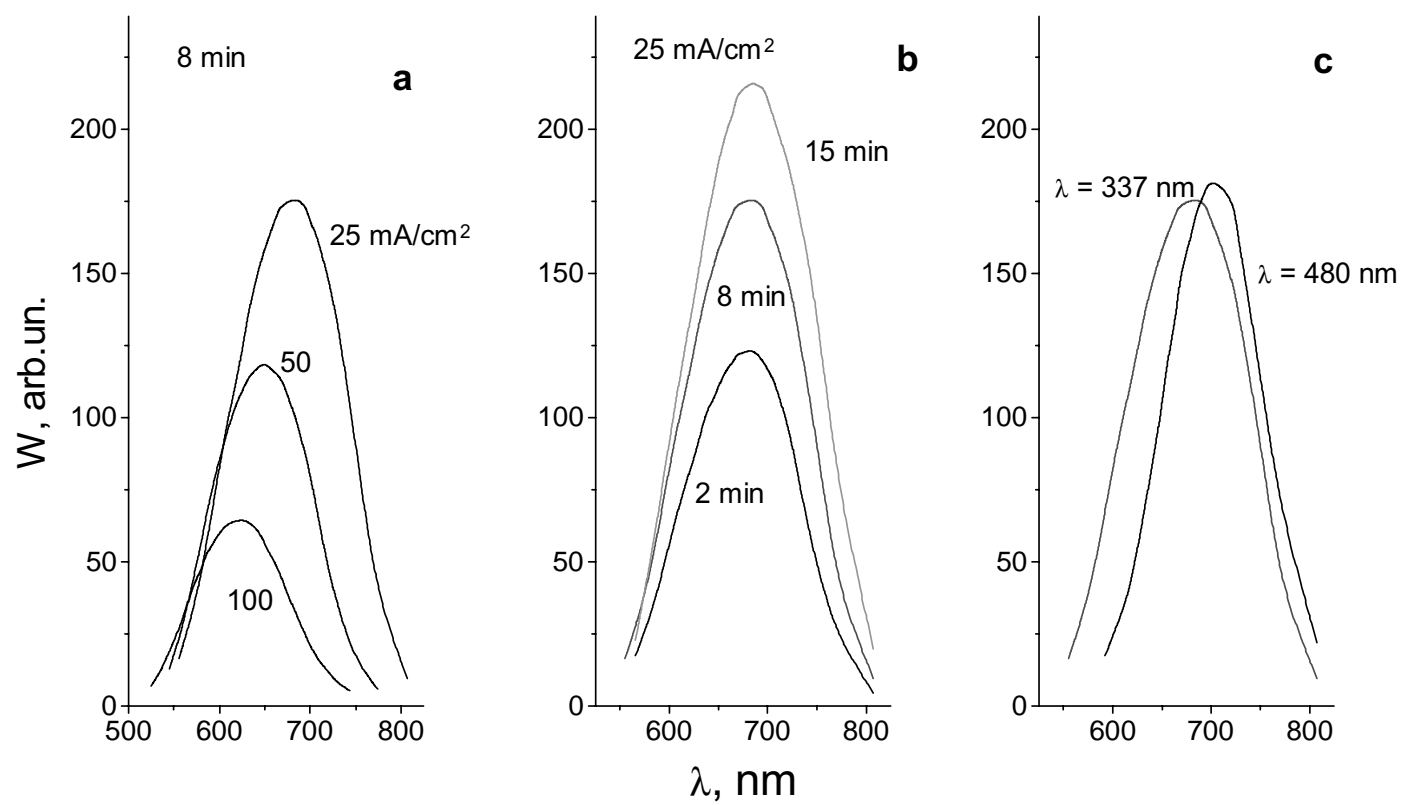

Fig. 1. PL spectra of as-prepared PS samples for different preparation conditions at the excitation wavelength $337 \mathrm{~nm}(\mathrm{a}, \mathrm{b})$ and for different excitation wavelengths (c).

a non-elementary nature of the PL band. The V excitation band corresponds to the PL component with longer wavelengths than that corresponding to the UV excitation, since an increase (decrease) in the $\mathrm{V}$ band intensity in PLE spectrum leads to a shift of the PL peak towards longer (shorter) wavelengths.

\subsection{Effect of the aging processes at the air, in a liquid, and in vacuum on the PL and PLE spectra}

The investigation of the PS aging process at the air has shown that its kinetics is different for the various light wavelength excitation and may be non-monotone. The PL intensity excited by light wavelength from the $\mathrm{V}$ band $(\lambda=480 \mathrm{~nm})$, when the contribution in the UV excitation band is negligible (fig. 3, curve 1), drops monotonical with time. The in- tensity of PL excited by the light wavelength from the UV band $(\lambda=330 \mathrm{~nm})$ first decreases insignificantly and then rises (fig. 3 , curve 2 ). When the PLE spectrum contains only the UV band, only an increase in the PL intensity is observed. Thus, during the process of aging, the $\mathrm{V}$ band in the PLE spectra decreases, and the UV band increases. So, there are two processes that take place during the aging. At the same time, the non-monotony of the curve 2 in fig. 3(a) is obviously due to their competition.

Different behavior of the V and UV bands in PLE spectra with respect to the anodization conditions and aging indicates the existence of two independent channels of PL excitation corresponding to these bands.

It is essential that a reduction of the excitation efficiency in the $\mathrm{V}$ band at the initial stage (fig. 3) is accompanied by a shift of the peak of the PL excited by the light from the UV and $\mathrm{V}$ bands towards shorter wavelengths (fig. 4). In addi-

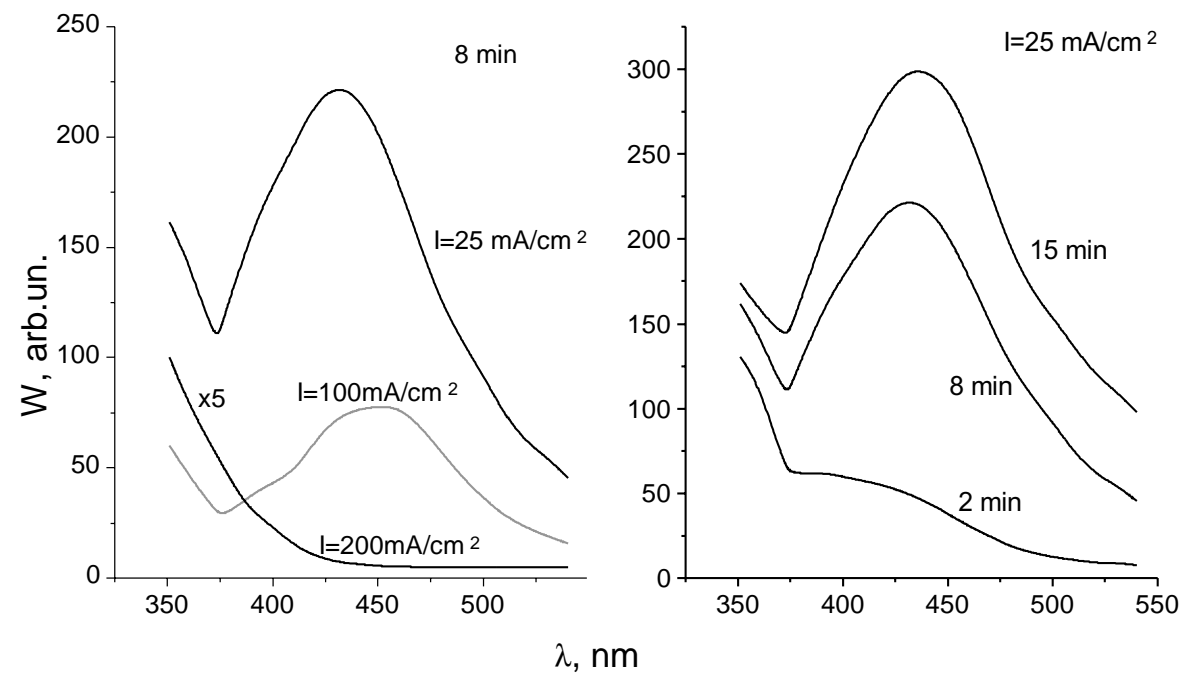

Fig. 2. PLE spectra measured at the luminescence peak energy for PS samples prepared under various conditions. 


\section{T. V. Torchinskaya et al.: Effect of desorption on photoluminescence excitation...}

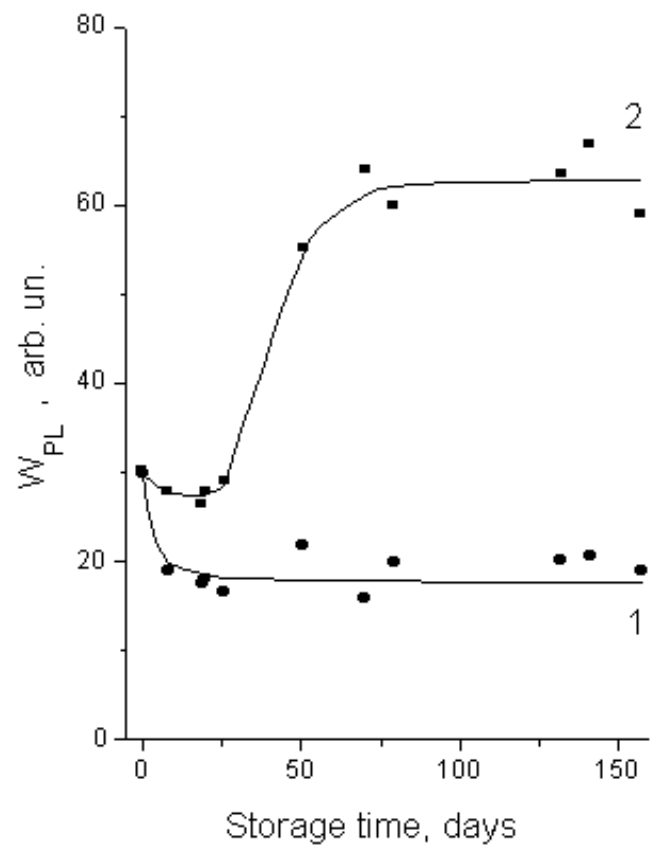

Fig. 3. Variation of the PL intensity caused by aging of PS samples: $1-480 \mathrm{~nm} ; 2-\lambda_{\text {exc }}=330 \mathrm{~nm}$.

tion, its FWHM decreases due to the prevalent drop of the long-wavelength component (fig. 4(a), curves 3 and 4).

To clarify the nature of the processes manifested by the transformations of the PL and PLE spectra during aging, we studied the effect of keeping of as-prepared porous $\mathrm{Si}$ samples in vacuum and in liquid (specifically, in water and in aqueous $\mathrm{NaCl}$ solution). The latter is often employed for electroluminescence studies. Keeping in vacuum was found to result only in a reduction of the PL intensity (fig. 5). In addition, the $\mathrm{V}$ band intensity in the PLE spectrum decreases (fig. 5(b), curve 2), while the shape of the PL band changes in the same way as during aging in the air. It is essential that the short-wavelength edges of the PL bands before and after keeping in vacuum coincide. This fact means that a drop of the PL intensity is associated not with an increase in the concentration of the nonradiative recombination centers, but with a reduction of the long-wavelength component. A similar behavior of PL is observed when keeping PS samples in $\mathrm{NaCl}$ solution (fig. 6).

To separate this component, let us analyze the data shown in fig. 5(a). The positions of $\mathrm{W}_{\mathrm{UV}}$ and $\mathrm{W}_{\mathrm{V}}$ peaks for as-prepared PS samples are different, but after keeping in vacuum they coincide. So, in these conditions the contribution of the long-wavelength component seems to be negligible. For this reason, the suppressed component can be separated by subtracting curve 2 from curve 1 . The result of this procedure is shown in fig. 5(a) (curve 5).

A similar behavior of the PL and PLE spectra at the initial stage of aging in the air and when keeping in vacuum leads us to the conclusion that the reduction of the PL intensity (its long-wavelength component) is caused by desorption of some substance from the surface of Si wires. Thus, one of the PL excitation channels is associated with a substance absorbed on the surface of Si wires (so-called surface excitation). Because of the overlapping of the excitation bands associated with two channels, the spectrum of the PL excited by the light from both the $\mathrm{V}$ band and the UV band may contain the long-wavelength component. Obviously, this may be the reason for the shift of the $\mathrm{W}_{\mathrm{V}}$ and $\mathrm{W}_{\mathrm{UV}}$ peaks after the treatments mentioned above.
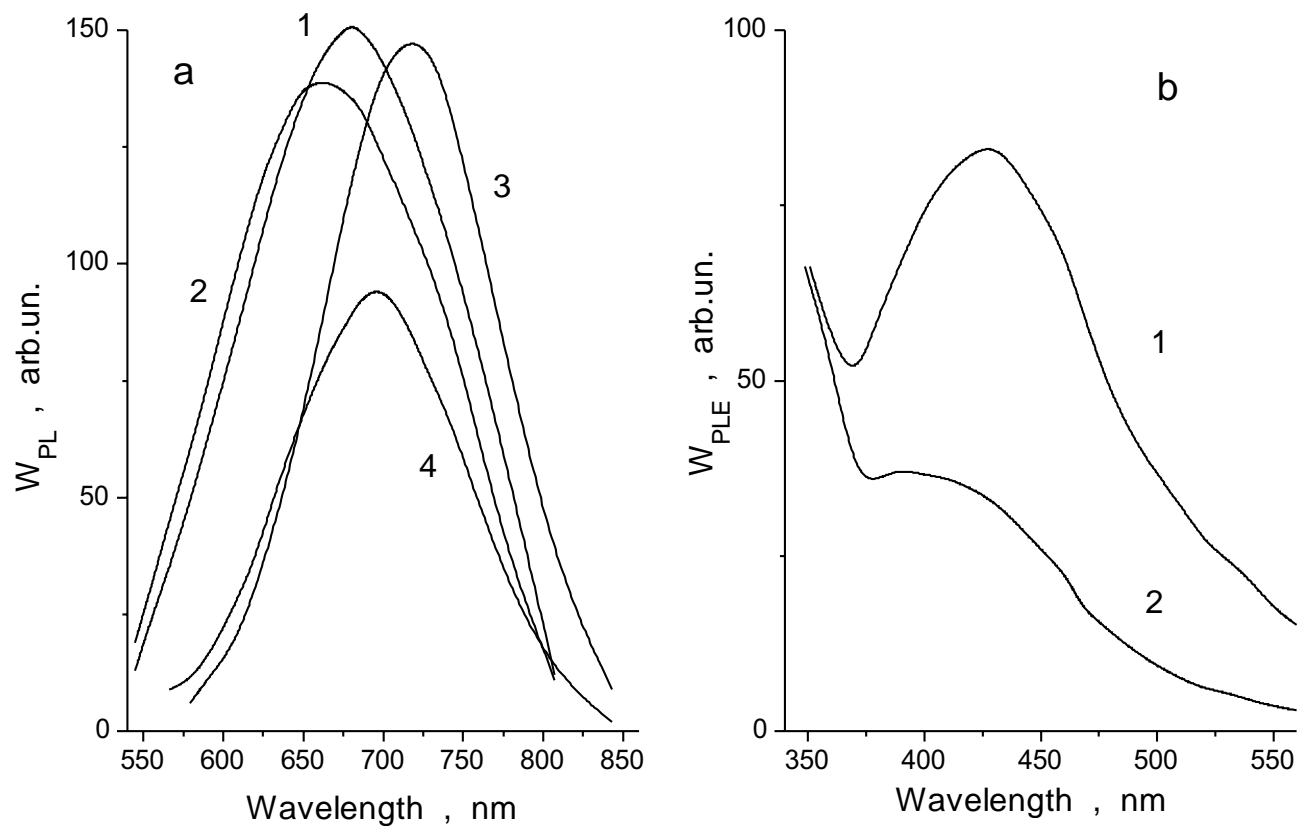

Fig. 4. Transformations of the PL and PLE spectra caused by aging in the air at $300 \mathrm{~K}$ : a) PL spectra at $\lambda_{\text {exc }}=337(1,2)$ and $480(3,4)$ nm of as-prepared $(1,3)$ and aged $(2,4)$ PS samples; curve 5 obtained by subtracting curve 2 from curve 1 ; b) PLE spectra of as-prepared (1) and aged for 7 days (2) PS samples. 


\section{T. V. Torchinskaya et al.: Effect of desorption on photoluminescence excitation...}
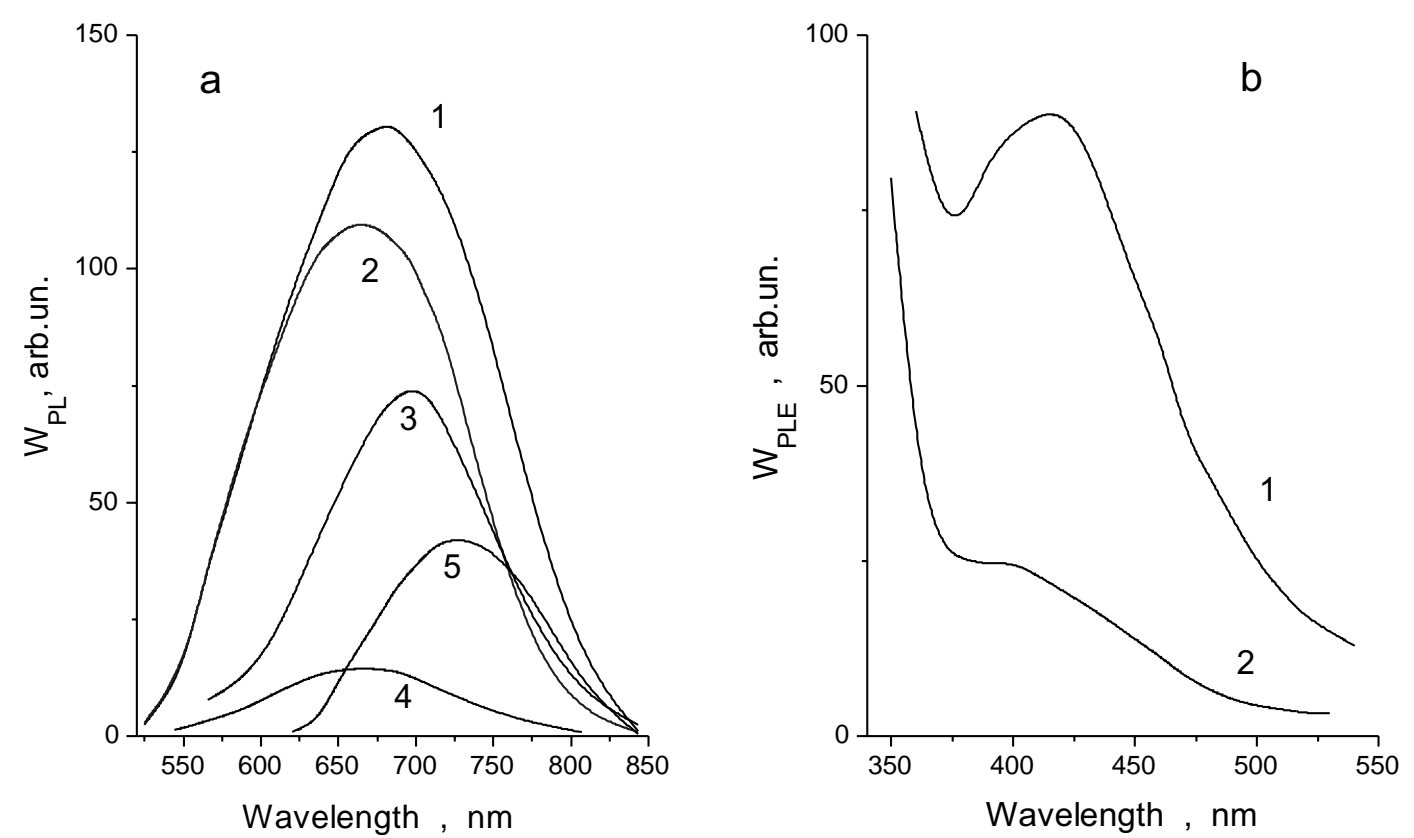

Fig. 5. Transformations of PL and PLE spectra caused by aging in vacuum at $300 \mathrm{~K}$ : a) PL spectra at $l_{\text {exc }}=330(1,2)$ and $480(3,4) \mathrm{nm}$ of as-prepared $(1,3)$ and aged $(2,4)$ PS samples; b) PLE spectra of as-prepared PS samples (1) and those kept in vacuum (2).

The infrared absorption spectrum of as-prepared PS exhibits a number of features which can be ascribed to the Si-H (800-900 $\left.\mathrm{cm}^{-1}, 2090-2140 \mathrm{~cm}^{-1}\right)$, Si-O $(1050$ $\left.-1170 \mathrm{~cm}^{-1}\right)$, O-Si-H $\left(2200-2240 \mathrm{~cm}^{-1}\right), \mathrm{C}-\mathrm{H}(2850$ $\left.-2930 \mathrm{~cm}^{-1}\right)$, and O-H $\left(1620 \mathrm{~cm}^{-1}, 3300-3600 \mathrm{~cm}^{-1}\right)$ bonds (Fig. 7). The presence of the $\mathrm{C}-\mathrm{H}$ related band is evidently caused by a component contained in the electrolyte - namely, ethanol. Fig. 7 (curve 2) shows the FTIR spectra of a PS sample after thermal treatment at $370 \mathrm{~K}$ for $1 \mathrm{~h}$. It is seen that the intensity of bands attributed to the $\mathrm{O}-\mathrm{H}$ and $\mathrm{C}-\mathrm{H}$ bonds decreases. At the same time, the $\mathrm{Si}-\mathrm{H}, \mathrm{Si}-\mathrm{O}$ and $\mathrm{O}-\mathrm{Si}-$ $\mathrm{H}$ related bands change insignificantly.

Therefore, the surface channel of PL excitation may be associated with ethanol or water. This conclusion is in agree-

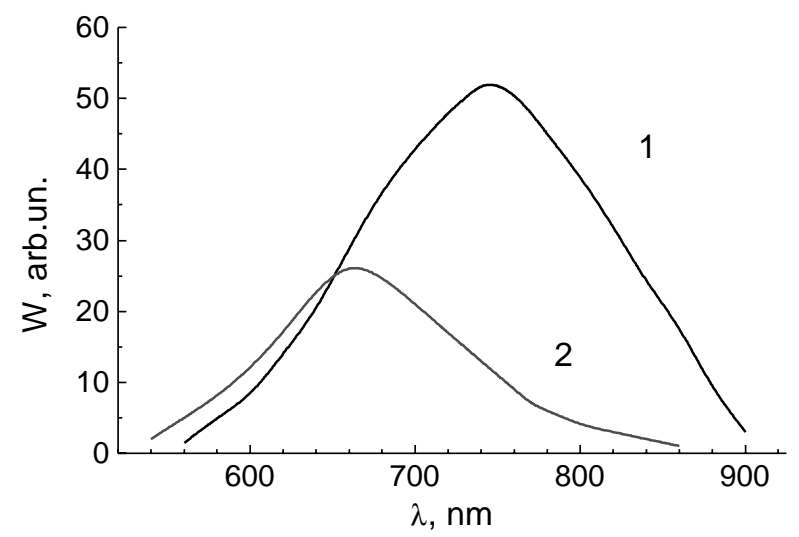

Fig. 6. PL spectra of as-prepared PS samples (1) and those kept in $\mathrm{NaCl}$ solution (2). ment with the data on the effect of pumping-out and water vapor treatment on the PL intensity [1].

It is known that water molecules do not have a light absorption band in the visible range of $350-450 \mathrm{~nm}$. However, water molecule complexes containing some impurities ( $\mathrm{Li}, \mathrm{Na}, \mathrm{K}, \mathrm{H}, \mathrm{CH}_{3}$, etc.) do exhibit a photoluminescence in the 350-500 nm range [2]. Thus, we can conclude that visible PL excitation may be caused by water complexes with some impurities, for example, $\mathrm{H}, \mathrm{CH}_{3}$ and, possibly, $\mathrm{F}$ and $\mathrm{B}$.

It should be noted that PL excitation in PS is usually attributed to light absorption in Si wires [3]. This conclusion is often based on analysis of PLE spectra similar to those shown in fig. 2(a) for PS samples prepared at $100 \mathrm{~mA} / \mathrm{cm}^{2}$, and on the assumption that in the limit of the optically thin sample the PLE signal is proportional to the absorption, provided that the quantum efficiency is independent of the exciting photon energy. From these spectra, the dependence of $\alpha(h v)$ was determined. It was attributed to two indirect light absorption transitions in Si. The shift of the absorption edge to higher energies in comparison to that in the bulk silicon was ascribed to the effect of quantum confinement [4]. Thus, the UV channel may be due to the absorption in Si wires, while, apparently, one cannot exclude the contribution of light absorption by suboxides on the surface of Si wires (see below).

We applied the analysis described above to both types of PLE spectra of our PS samples (fig. 2(a)). The PLE signal detected near the luminescence peak energy is shown in fig. 8 as a function of the excitation energy. For low excitation energies, the signal in the PLE spectra of the first type (fig. 8, curve 1$)$ follows the dependence $\left(\alpha_{\mathrm{PLE}} h v\right)^{1 / 2} \sim$ 
T. V. Torchinskaya et al.: Effect of desorption on photoluminescence excitation...

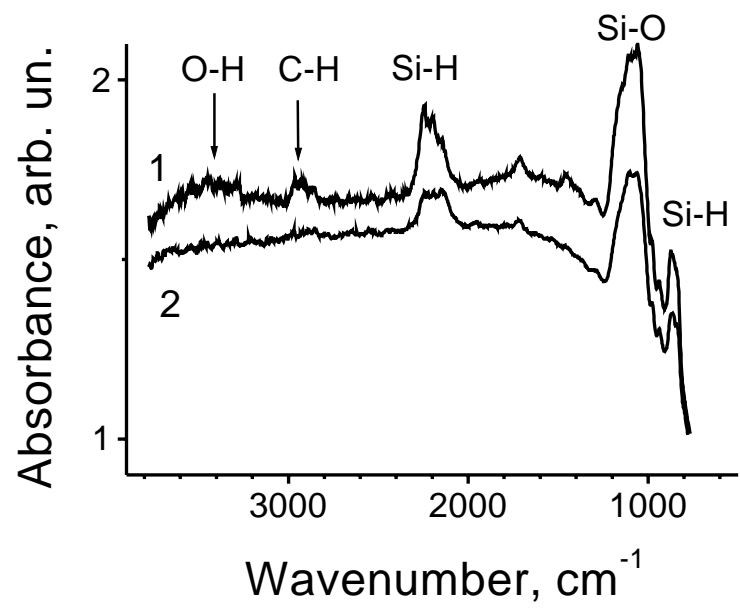

Fig. 7. FTIR spectra of PS samples: as-prepared (1) and thermally treated at $370 \mathrm{~K}$ for $1 \mathrm{~h}(2)$.

$\sim\left(h v-\mathrm{E}_{\mathrm{e}}\right)$ with two different slopes and two cut-offs at $\mathrm{E}_{\mathrm{el}}=$ $=1.9,2.2 \mathrm{eV}$ and $\mathrm{E}_{\mathrm{e} 2}=2.4,2.7 \mathrm{eV}$. At the same time, for low excitation energies, the signal in the PLE spectra of the second type (fig. 8, curve 2) is also described by the same kind of dependence (cut-off at $\mathrm{E}_{\mathrm{e} 1}=1.9,2.2 \mathrm{eV}$ ). So, for both cases, the light absorption dependences correspond to indirect transitions.

We should conclude that the light absorption of some species on the surface of $\mathrm{Si}$ wires is also characterized by the dependence $\left(\alpha_{\mathrm{PLE}} h v\right)^{1 / 2} \sim h v$. This dependence agrees with the assumption that these species are complexes (or clusters). Thus, the dependence $\left(\alpha_{\mathrm{PLE}} h v\right)^{1 / 2} \sim\left(h v-\mathrm{E}_{\mathrm{e} 1}\right)$ and the absorption edge at $\mathrm{E}_{\mathrm{el}}=1.9,2.2 \mathrm{eV}$ can be due to light absorption not only in $\mathrm{Si}$ wires, but also in some complexes on their surface. So, this kind of light absorption behavior cannot be considered as an evidence of absorption in $\mathrm{Si}$ wires.

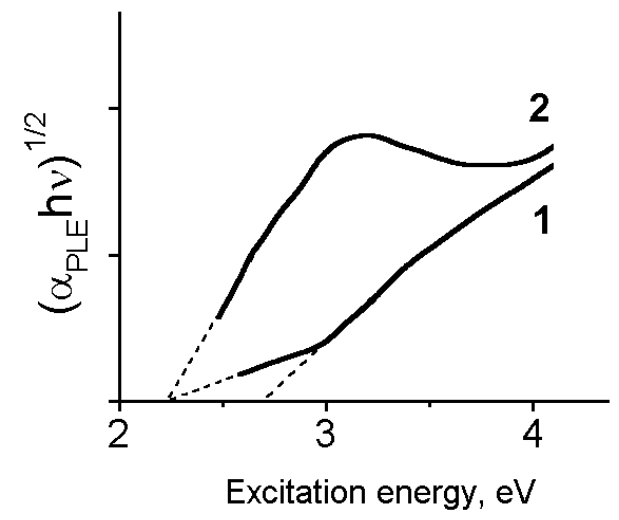

Fig. 8. The dependence of the PLE signal on the excitation photon energy for two PS samples prepared at current densities $I_{a}=25$ (1) and $100(2) \mathrm{mA} / \mathrm{cm}^{2}$ for the same time $t=8 \mathrm{~min}$.

\section{Conclusions}

There are two types of PLE spectra in porous silicon containing two (visible and ultraviolet) or one (only ultraviolet) bands. We have shown that the visible PLE band at $300 \mathrm{~K}$ is associated with some complexes (water molecules with impurities) on the surfaces of Si wires.

This work was supported by the Ministry of Science and Technology of Ukraine and the Ministry of Sciences of Israel (grant 2M/1406).

\section{References}

1. M. S. Brodin, V. N. Bykov, D. B. Dan'ko, Ukr. Fiz. Zhurn., 40, p. 933 (1995).

2. J. Stauff, J. Chem. Physik 74(1970)358.

3. L. Wang, M. T. Wilson, N. M. Haegel, Appl. Phys. Lett. 62(1993)1113.

4. M. Ben-chorin, B. Averbukh, D. Kovalev, G. Polisski, F. Koch, Phys. Rev. Lett. 77(1996)763

\title{
ВПЛИВ ПРОЦЕСУ ДЕСОРБЦЇ̈ НА СПЕКТРИ ЗБУДЖЕННЯ ФОТОЛЮМІНЕСЦЕНЦЇ ПОРИСТОГО КРЕМНIЮ
}

\author{
Т. В. Торчинська, Н. О. Корсунська, Л. Ю. Хоменкова, Б. Р. Дюумаєв, А. Мені , Ю. Голдстейн *, Е. Савір* \\ Інститут фізики напівпровідників НАН Украӥни \\ *Раках Інститут фізики, Хебрю Університет, Ізраӥль
}

Резюме. Досліджено механізм збудження фотолюмінесценції пористого кремміго методами фотолюмінесценції та інфрачервоного поглинання. Показано, що існує два типі спектрів збудження, які містять або дві смуги (видиму та ультрафіолетову), або тільки одну (ультрафіолетову) смугу. Вивчено залежності інтенсивностей кожної смуги від режимів електрохімічного травлення, а також їх поведінка у процесі старіння та термічного оброблення пористих шарів. Показано, що існують два канали збудження фотолюмінесценції. Видима смуга у спектрі збудження при 300 К пов'язується 3 поглинанням світла у речовинах, які адсорбовані на поверхні кремнієвих ниток.

\section{ВЛИЯНИЕ ПРОЦЕССА ДЕСОРБЦИИ НА СПЕКТРЫ ВОЗБУЖДЕНИЯ ФОТОЛЮМИНЕСЦЕНЦИИ ПОРИСТОГО КРЕМНИЯ}

\author{
Т. В. Торчинская, Н. Е. Корсунская, Л. Ю. Хоменкова, Б. Р. Дюсумаев, А. Мэни *, Ю. Голдстейн *, Э. Савир* \\ Институт физики полупроводников НАН Украины \\ *Раках Институт физики, Хебрю Университет, Израиль
}

Резюме. Исследован механизм возбуждении фотолюминесценции пористого кремнии методами фотолюминесценции и инфракрасного поглощения. Показано, что существуют два типа спектров возбуждения, которые содержат либо две полосы (видимую и ультрафиолетовую), либо только одну (ультрафиолетовую) полосу. Изучены зависимости ингенсивностей каждой полосы возбуждения от режимов электрохимического травления, а также их поведение в процессе старения и термических обработок пористых слоев. Показано, что существуют два канала возбуждения фотолюминесценции. Видимая полоса в спектре возбуждения при 300 К связывается с поглощением света веществами, адсорбированными на поверхности кремниевых нитей. 